\title{
Flashcard for Enriching and Developing the Child Vocabulary with Speech Delay to Improve Lingual Skill
}

\author{
C Dahniarti ${ }^{1 *}, \mathbf{M ~ S i t i ~}^{1}$, and A Fajar ${ }^{1}$ \\ ${ }^{1}$ Universitas Negeri Surabaya, INDONESIA
}

Received 4 August 2019 - Revised 2 October 2019 - Accepted 26 October 2019

\begin{abstract}
This study aims to know the effectiveness of STEM integrated handouts to improve This study aims to enrich and developing vocabulary the child with speech delay by using flashcard. The subject of the research is the child who was late in speaking due to sensory disorders, Kindergarten 1 , the age of 4 years old. The research method was single subject research quantitative research (single subject research). Techniques of analysis the data collection through observation of baseline $A$ and $B$, also documentation. The Results showed that baseline phase (A) phase to the intervention (B) are increasing, which means that the condition has increased after the intervention. Where in the baseline-2 (A2) phase to intervention (B) it is increased which means that the intervention can significantly improve the ability of the subject
\end{abstract}

Keywords: flashcard, vocabulary, speech delay. lingual skill

\section{INTRODUCTION}

Jamaris stated that vocabulary is the development of children's language. Language development in early childhood is very important because language is the basisc of the ability of a child; through the development of a good language it can improve the other's ability, to know something around the social environment first then other knowledge[1]. The development of children's language according to age and the environment around the child is very supportive, it is growing and complex.

For enriching and developing the child vocabulary with speech delay, need to selection for learning vocabulary. Selection of media for learning vocabulary by considering all aspects. One of the media that can be applied is a flashcard media. Based on research by Nugroho, Nurkamto, and Sulistyowati found that using flashcards can improve student's vocabulary skills, flashcards can attract students' attention, motivated, and focused on learning vocabulary[2].

\section{Instructional Media}

Martin and Briggs said that learning media is a source needed to communicate with children[3]. Intructional media according to Seels and Richey, media can be divided into four[4], namely: 1) media produced by print technology, namely technology that produces material in printed forms such as text, graphics, photos; 2) the media resulting from audio-visual technology, namely how to deliver material using hardware such as projectors, tape recorders so that the learning process through view and hearing; 3) media based on technology based on computers, namely the way of delivering material using microprocessor-based sources and panic material in digital form; 4) media combined results of print and computer technology, namely the method of delivering material combining several forms of media controlled by computers.

(C) 2019 by the authors; licensee PGSD UMP. This article is an open access article distributed under the terms and conditions of the Creative Commons Attribution License (http://creativecommons.org/licenses/by/4.0/).

dahniarti.17070905015@mhs.unesa.ac.id (*Correspondence) 


\section{Selection of Intructional Media}

Mustaji argued several things that need to be considered in the selection of learning media[5] such as: a) achievement of learning objectives $b$ ) media users, to adjust to user characteristics $c$ ) characteristics of the media to be used. d) use of time to be used. e) costs needed to determine and choose media f) media can be easily obtained is a consideration also in choosing the media to be used. g) the need to know the conditions and strategies in using the media. h) technical quality is the criterion for selecting media that is ready for use, such as audio, video, graphic or print media programs. Anderson stated several steps in choosing the media, the first step is to determine project objectives that are information or learning, the second step determines the transmission method, the third step determines the characteristics of the lesson, step four selects the first category of media, fifth analyzes the characteristics typical of the media[6].

\section{Flashcard Media}

Flashcard is a small card that contains images, text, or symbols that can be used to make it easier to remember or retain students to connect with the images used to spell and enrich vocabulary [6]. Flashcards are units of cards that contain information, including words, pictures, or numbers, located on both sides, can be used to study indoors or individual learning. Hudson, Taglieber, Johnson and Yarbrough argued that images on flash cards can help improve children's good memory, because visuals have a big influence on remembering and understanding something compared to using verbal / audio[7].

Flashcard is media that can be used to help students and teachers in learning [2]. Based on research conducted by Nugroho et al. (2012) that the flash cards used can improve students 'vocabulary skills because of flash cards a media that attracts students' attention so students are motivated and focused on getting to know vocabulary [2]. Images are easy to remember compared to words that are concrete, and are easy to store in memory [9]. The results of Fitriyani and Nulanda's research media flashcard can help students learn more focus and can get to know words easily[10].

\section{Early Childhood Language Development}

Language has a function to express desires both in the form of verbal and non verbal and is used to socialize with the community. Sonawat and Jasmine Maria Francis in Usman [11] argued five language functions, namely: 1) language is a tool that can be used to express desires; 2) language is a tool that can be used to express emotions; 3) language is a tool that can be used to obtain information; 4) language is a tool that can be used to interact socially; and 5) language is a personal identification tool. Language has the function of manifesting feelings in every human being expressed through expressing desires, and emotions. Language is essentially a tool that can be used to communicate and socialize with the environment. Usman presented three views or theories in children's language development[11]. The theory is as follows: 1) nativis theory; 2) behavioristic theory; 3) cognitive theory; and, 4) vygotsky theory [12]. It can be understood that language as a tool that can help children solve problems faced and basically all children have been given gifts from the khalik to be able to make sounds or sounds, and with the environment, the culture of the community will make it easier for children to know and know vocabulary word, and the desire of the child's knowledge that involves his intellectual to be able to interact with the social environment that can stimulate language on him.

\section{Characteristics of Early Childhood Ability of Language}

Early childhood language skills in each child vary in each age level. Jamaris (2006) stated the characteristics of language skills of 4-year-olds are[1]: a) rapid development in children's language skills, in which children can use sentences properly and correctly; b) children can master 90 percent of the phonemes and syntax of the language they use c) children can participate in a conversation, children can hear other people talking and responding to the conversation. It can be understood that children aged 4-5 years have developed in aspects of the language that are indicated by the ability of children to participate in conversations both with peers and adults around them.

\section{Speech Delay}

Speech delay is a tendency where children find it difficult to express their desires or feelings to others such as being unable to speak clearly, and lack of vocabulary mastery that makes the child different from other children of his age. Hurlock (1978: 194-196) stated "if the level of speech development is below the level of quality of speech development, the child of the same age can be known[13]. Some types of speech delay have differences with one another as indicated by disorders experienced of the children. The types of speech delay to early childhood according to Van Tiel [14](Tsuraya 2013: 25): 1) Specific Language Impairment; 2) Speech and Language Expressive Disorder; 3) Centrum Auditory Processing Disorder; 4) Pure Dysphatic Development; 5) Gifted Visual Spatial Learner; 6) Disynchronous Developmental. Delay in speaking is not only a child's 
developmental factor, but also due to sensory disorders, neorological disorders, intelligence, personality and internal development imbalances and imbalances in the child's external development.

\title{
MATERIAL AND METHODS
}

\begin{abstract}
Methods
The researcher use single subject research quantitative research (single subject research) Single subject experimental design is a design that can be used if the sample size is one

\section{Instrument}

The conception test instrument that was developed to find out the conception of preservice elementary school teacher students was 7 items. Test items used the four-tier test format. The conception test validation was judged by two physics education experts and one theoretical physicist. The results of the validation of the conception test items indicated that the validator generally stated that the items to be used are valid both in content and construction. Validators provided some notes that are suggested to be revised, especially those that are considered inappropriate, that is, related to accepted scientific theory, image clarity, sentence editorial, and written order. The research instrument was in the form of several multiple-choice items on the concept of force and motion that require explanations about the selected answers. To find out the participants' conceptual change, they wrote their responses towards several written statements (Yes/No/Not always) and with confidence levels (Sure/Not really sure/Not sure). The participants answered the questions individually and do not include their names to ensure their anonymity.
\end{abstract}

\section{Procedures}

This study uses single subject research (SSR) using the A1 - B-A2 design. A1 is a baseline condition where this condition is the best estimate of the treatment given. $\mathrm{B}$ is an intervention condition which is a condition when the intervention is given later in that condition can be measured. A2 is a phase that allows to draw conclusions about the relationship between the independent variable and the dependent variable.

A1: (baseline 1) in this study is a basic ability in this case ability speak early in the subject. The subjects were given instructions to view 3 flash card media and give an answer according to the picture he saw and pronounce the word this thing that becomes the initial ability

possessed by the subject.

B: (intervention) by giving training in image recognition by pronouncing vocabulary the right word with the appropriate image sequence until you can say it to 1 sentence.

A2: (baseline 2) is a re-observation of the ability to speak and be evaluation to determine the effect of giving intervention on the subject's ability.

Variables are terms in experimental research including research with a single subject which is an attribute about something observed in research (Sunanto, Takeuchi, and Nakata (2005:12) Variables are forms of events that can be observed and measured, variables used are variables that influenced by independent variables and dependent variables, in this study the dependent variable is vocabulary understanding while the independent variable is flash card media[16].

The subjects in this study were children who were late in speaking due to sensory disorders, Kindergarten 1 of Logos Christian School, Surabaya, the age of 4 years. The characteristics of the research subjects are in expressing the language, having difficulties in understanding the questions given by the teacher, difficulties in delivering sentences completely and clearly, students cannot tell stories, students have not been able to provide information accurately and clearly, and always repeat the words the same one.

\section{Data Analysis}

The analysis used was analysis in conditions and analysis between conditions. The data obtained by researchers from the results of research on the application of flash card media to improve vocabulary understanding, consisted of 8 sessions: 2 baseline- 1 sessions (A1), 3 intervention sessions (B) and 3 baseline- 1 sessions (A2). 


\title{
RESULTS AND DISCUSSION
}

\author{
Analysis in Conditions
}

After analysis in conditions, the results of data analysis were in the conditions of baseline-1 (A1) phase, intervention phase (B) and baseline phase-2 (A2). Conduction length or the number of all sessions conducted in the baseline-1 (A1) phase are 2 sessions, the intervention phase (B) is 4 sessions, and the baseline-2 phase (A2) is 2 sessions. Estimates of direction trends explain changes in each data from session to session. Baseline-1 (A1) phase of the flat direction trend because the scores obtained are the same from the last first session. Intervention phase (B) trend line direction increases because the score obtained increases from the last first-session session.

\begin{tabular}{|c|c|c|c|c|c|}
\hline \multicolumn{2}{|c|}{ Fase Base line-1 } & \multicolumn{2}{|c|}{ Fase Intervention } & \multicolumn{2}{|c|}{ Fase Base line-2 } \\
\hline \multicolumn{2}{|c|}{ (A1) } & \multicolumn{2}{|c|}{ (B) } & \multicolumn{2}{|c|}{ (A2) } \\
\hline Session Number & Percent & Session Number & Percent & Session Number & Percent \\
\hline 1 & $25 \%$ & 3 & $42 \%$ & 7 & $75 \%$ \\
\hline \multirow[t]{3}{*}{2} & $25 \%$ & 4 & $42 \%$ & 8 & $75 \%$ \\
\hline & & 5 & $58 \%$ & & \\
\hline & & 6 & $58 \%$ & & \\
\hline
\end{tabular}

The calculation of the stability tendency in the baseline-1 (A1) phase is $100 \%$, the intervention phase (B) is $100 \%$, and the basseline-2 (A2) phase is $100 \%$. Can be seen in all three phases having a tendency for data stability to be stable. In the baseline phase-1 (A1) the data trace is the same. Intervention phase (B) the data trace increases and the baseline-2 (A2) phase of the data trace increases. The beseline-1 (A1) phase data are equally stable with a range of 25-25, the intervention phase (B) increases stably with a range of $42-58$, and the baseline-2 phase (A2) increases stably with a range of 75-75. The level of change in the baseline-1 (A1) phase shows the same, the intervention phase (B) shows a sign $(+)$ which means increasing, and the baseline-2 phase (A2) shows a sign $(+)$ which means increasing.

\section{Inter-Condition Analysis}

Inter-conidition analysis is an analyzing activity carried out between two conditions, namely baseline conditions and intervention conditions. Analysis between conditions is carried out after the data obtained shows stability. In this study one variable that you want to change is one, the ability to recognize vocabulary.

Changes in the tendency of the direction between the baseline-1 (A1) phase to the intervention (B) are increasing, which means that the condition has increased after the intervention. Whereas in the baseline-2 (A2) phase to intervention (B) it is increased which means that the intervention can significantly improve the ability of the subject. Changes in the tendency for stability between baseline-A1 (A1) to intervention (B) is stable to stable, and between baseline-2 (A2) to intervention (B) is stable to satabil.

Changes in level from baseline-1 (A1) to intervention (B) of +17 which means the ability to understand vocabulary has increased by +17 . Whereas from baseline- 2 (A2) to intervention is 0 which means the vocabulary ability remains the same even though the intervention has not been given.

The overlapping data in the baseline- 1 (A1) phase into the intervention (B) is $0 \%$, which means that giving the intervention has a significant influence on the behavior. In other words, flash card media helps in understanding vocabulary in children, the delay in talking at TK A.

\section{The Student Ability of Speech Delay}

The baseline condition is the initial condition to determine the ability of students before intervention or treatment. The condition before being given an intervention showed the ability to understand vocabulary in the research subjects had a low score. This can be seen from the calculation of data analysis under conditions in the beseline-1 (A1) phase with a mean level of 25 , the estimated data trace is the same because the same score is obtained.

The intervention provided is in the form of the application of flash card media which is one of the learning media that is used as a strategy in delivering messages to students. In the implementation of using flash card the students' vocabulary ability has increased. Understanding using flash card media can help understand and remember the vocabulary learned. This can be seen in the values obtained by the research subjects, namely $42 \%$, $42 \%, 58 \%$, and $58 \%$.

Research on the application of flash card media to the ability to understand vocabulary shows that with flash card media can improve students' vocabulary understanding of delay in talking with sensory disorders. This situation is indicated by the ability to recognize vocabulary at baseline-1 (A1) for 2 sessions. The value obtained is a score of $25 \%, 25 \%$. Increased intervention phase (B) which is a score of $42 \%, 42 \%, 58 \%, 58 \%$, for 4 sessions. Baseline- 2 phase (A2) is a score of $75 \%$, and $75 \%$. The percentage of baseline- 1 (A1) stability is $100 \%$, intervention (B) is $100 \%$ and baseline-2 (A2) is $100 \%$, which means that the three phases have a stable percentage of stability. 


\section{CONCLUSION}

Based on the results and discussion can be concluded that student with speech delay can be improved lingual skill by using flashcard. The reason according to the research are: (1) Flashcard can easily to use and can attaract attention; (2) Flashcard help the student with speech delay to focus leaning vocabulary; and (3) Flashcard can help the student with speech delay to speak complete sentances. Thus, flashcard media is one of the instructional media that can be used in the learning process. In this research flashcard can improve lingual skill. Teacher can use flashcard to help the student with speed delay to enrich and develop the vocabulary to improve lingual skill

\section{REFERENCES}

(1) Jamaris, M. (2006). Perkembangan dan pengembangan anak usia taman kanak-kanak. Jakarta: Grasindo.

(2) Nugroho, Nurkamto, \& Sulistyowati (2012). Improving Students' Vocabulary matery Using Flashcards. English Education Journal.

(3) Martin, B. L., \& Briggs, L. J. (1986). The affective and cognitive domains: Integration for instruction and research. Educational Technology.

(4) Arsyad, A. (2011) Media Pembelajaran. Jakarta: Rajagrafindo Persada.

(5) Mustaji, (2016). Media Pembelajaran. Surabaya: Unesa University Press.

(6) Mohammadnejad, S., Nikdel, H., \& Oroujlou, N. (2012). Reactivating EFL Learner's Word Knowledge by Means of Two Technique: Flashcards versus Worldlist, International Journal of Linguistic.

(7) Carpenter, S. K., \& Olson, K. M. (2012). Are pictures good for learning new vocabulary in a foreign language? Only if you think they are not. Journal of Experimental Psychology: Learning, Memory, and Cognition, 38(1), 92. (5) Komachali, M.E. \& Khodareza, M.(2012). International Education Studies teh Effect of Using Vocabulary Flash Card on Irianian Pre-University Students Vocabulary Knowledge, International Education Studies.

(9) Nashir, M. and R.N. Laili .(2018). The implementation of electronic flashcard to increase students' vocabulary. Edukasi: Jurnal Penelitian dan Artikel Pendidikan, 10 (2), 125-136

(10) Fitriyani, E., \& Nulanda, P. Z. (2017). Efektivitas Media Flash Cards dalam Meningkatkan Kosakata Bahasa Inggris. Psympathic: Jurnal Ilmiah Psikologi, 4(2), 167-182.

(11) Usman, M. (2015). Perkembangan Bahasa Dalam Bermain dan Permainan Yogyakarta: Deepublish (CV.Budi Utama

(12) Teng, F. and He, F. (2015) An Example of Classroom Practice Using Flashcards for Young Learnes: Preliminary Indications for Promoting Autonomy. SiSal Journal Vol. 6, N0. 4, Desember 2015, 382-398.

(13) Hurlock B.E. (1978) Perkembangan Anak Jilid 1. Jakarta: Erlangga.

(14) Tsuraya, I. (2013). Kecemasan Pada Orang Tua Yang Memiliki Anak Terlambat Bicara (Speech Delay) Di RSUD Dr. Ashari Pemalang. Skipsi, (Online), Jilid 2 Vol 2 . ISSN 22526358 (http:/ / www.google.co.id/18524/1/1550408058.pdf\&sa=U\&rct=j\&ved=0ahUKEwiZ19HG64jLAhWKco4K He0SAJUQFggbMAA\&sig2=nKOqlQiYzKWwBfw0oo2stQ\&usg=AFQJCNFCxoEzNKoSSk9t7kah1jnQ3FM3 tg diakses 30 Februari 2019).

\section{http://www.jurnalnasionalump/index.php/dinamika}

